\title{
ARTIKELEN
}

\author{
THEMA-ARTIKEL
}

\section{Op zoek naar succesvol gezag in het lokaal bestuur* $^{*}$}

\author{
Thijs Jansen \& Corné van der Meulen
}

\begin{abstract}
'Besturen in Nederland is er de afgelopen decennia niet makkelijker op geworden: het gezag van ambtsdragers wordt in toenemende mate betwist.' Dit was de opening van het artikel 'Veranderend lokaal gezag. De gezagsbronnen van burgemeesters en wethouders verkend', dat Niels Karsten en Thijs Jansen in 2013 publiceerden (Karsten \& Jansen, 2013). Zeven jaar later is die uitspraak bepaald niet minder waar en daarom kan deze inleiding van dit themadeel over gezag in lokaal bestuur met diezelfde zin openen.

Een blik op de getallen van vertrekkende lokale bestuurders en ambtenaren leert dat het nog onverminderd hectisch is in het lokaal bestuur. In januari van dit jaar bleek - uit een onderzoek in opdracht van het blad Binnenlands Bestuur - dat in 2019126 van de 1144 wethouders in Nederland gedwongen waren om af te treden. ${ }^{1}$ Dat is het hoogste aantal in vijftien jaar. Er is ook veel meer verloop onder gemeentesecretarissen. Vroeger bleven zij vaak in functie tot hun pensioen, tegenwoordig is hun gemiddelde zittingsduur in eenzelfde gemeente vijf jaar (Boonstra, 2019).
\end{abstract}

Het is daarom uitermate relevant om meer te weten te komen over hoe verschillende belangrijke functies in het lokaal bestuur succesvol en geloofwaardig kunnen worden bekleed. In dit tijdschrift is al eerder aandacht aan dit thema besteed. Zo verscheen in 2018 het themanummer 'Gezag en geloofwaardigheid van lokale politieke bestuurders' (Brons \& Jansen, 2018). Het is verheugend te noemen dat er in de afgelopen jaren steeds meer onderzoek is verricht naar 'gezag' in het lokaal bestuur (o.a. Van der Meulen, Jansen \& Karsten, 2019; Van der Meulen \& Jansen, 2018; Van der Meulen, Jansen \& Karsten, 2018; Karsten, 2015; Karsten, 2013). Verenigingen van wethouders, gemeentesecretarissen, griffiers en raadsleden zijn ook zeer geïnteresseerd in onderzoek dat praktische handvatten kan bieden. Dit nummer bevat artikelen die aanknopingspunten bieden voor dergelijke handvatten, omdat de onderzoekers nadrukkelijk op zoek

* Drs. T. Jansen is directeur van Stichting Beroepseer en senior wetenschappelijk projectmedewerker bij Centrum Èthos (Vrije Universiteit, Amsterdam).

C. van der Meulen MSc is projectleider/onderzoeker (www.beroepseer.nl) bij Stichting Beroepseer en doet onder andere onderzoek naar gezag in het lokaal bestuur.

1 Zie '126 wethouders kwamen in 2019 ten val, hoogste aantal in vijftien jaar', https://nos.nl/ artikel/2317867-126-wethouders-kwamen-in-2019-ten-val-hoogste-aantal-in-vijftien-jaar.html. 
zijn gegaan naar succesfactoren in het functioneren van gemeentesecretarissen en wethouders.

Frans-Willem van Gils heeft een kwalitatief onderzoek gedaan naar de succesfactoren van de werkrelatie burgemeester-gemeentesecretaris. Hiertoe heeft hij in totaal 72 empirische werkrelaties verdeeld over 36 gemeenten geanalyseerd. Een van de interessante aanbevelingen waarmee Van Gils zijn artikel beëindigt, is: 'Veel wetenschap blijft verborgen achter de gesloten deuren van het "inner sanctum". Om die reden de aanbeveling: open de deuren. In aanvulling op de reeds bestaande initiatieven van de beide beroepsverenigingen (zoals publicaties en intervisiebijeenkomsten) zouden gezamenlijke bijeenkomsten van burgemeesters en gemeentesecretarissen een bijdrage kunnen leveren aan wederzijds zicht op en begrip voor elkaars uitdagingen.'

Corné van der Meulen, Thijs Jansen en Niels Karsten hebben op verzoek van de Vereniging voor Gemeentesecretarissen een enquête onder deze beroepsgroep uitgezet om te achterhalen welke bronnen secretarissen het belangrijkst vinden om gezagsvol te kunnen handelen. De uitkomsten hiervan worden ook vergeleken met de gezagsbronnen die burgemeesters en wethouders voor hun eigen functioneren effectief vinden. Daarnaast is gevraagd hoe gemeentesecretarissen hun gezag inschatten in de verschillende arena's waarin zij opereren: respectievelijk het college van B\&W, de ambtelijke organisatie, de gemeenteraad en de samenleving. In totaal heeft meer dan 30 procent van de gemeentesecretarissen in Nederland de vragenlijst ingevuld. De auteurs concluderen dat de meeste gemeentesecretarissen hun gezagspositie hoog inschatten en dat ze mee zijn gegaan met de maatschappelijke verschuiving waarin gezag op individueel niveau moet worden verdiend. Ze waarschuwen: 'Maar hoe zorgvuldig en bewust een gemeentesecretaris ook met zijn gezagspositie omgaat, het risico om het gezag in een hoog tempo weer kwijt te spelen ligt altijd op de loer. Gezag moet dag in dag uit, steeds opnieuw, worden verdiend in allerlei omstandigheden en ten overstaan van verschillende partijen.'

Dit nummer bevat ook een interview met gemeentesecretaris Boudewijn Marinussen. Hij is gepokt en gemazeld in gemeenteland. Met zijn rijke ervaring kent hij de complexe balansfunctie van gemeentesecretaris als geen ander. Marinussen functioneert als klankbord voor collega's in zijn rol als vertrouwenspersoon bij de Vereniging voor Gemeentesecretarissen. Gerard van Nunen interviewde hem: Welke gezagsbronnen zijn tegenwoordig onontbeerlijk? Hoe wordt een verlies aan gezag veroorzaakt, en is er na verlies een kans op herstel?

$\mathrm{Na}$ drie artikelen over het gezag van de gemeentesecretaris eindigt het themadeel met een artikel over het gezag van de wethouder. Peter Verheij heeft in zijn onderzoek succesvol wethouderschap onder de loep genomen. Interessant is dat hij dat gedaan heeft door de ogen van inwoners, raadsleden en wethouders zelf. Welke indicatoren van legitimiteit en lokaal politiek leiderschap maken wethouders in Nederland anno 2020 succesvol? Hoe kunnen verschillen tussen de perspectieven van inwoners, raadsleden en wethouders verklaard en geduid worden? De survey is door ruim 1000 inwoners, 650 raadsleden en 300 wethouders ingevuld. Verheij eindigt zijn artikel met praktische aanbevelingen, waarvan deze in het bijzonder opvallen: '(...) dat de oordelen die wethouders zichzelf aanmeten, 
zowel in deze studie als in bijvoorbeeld de Beste Bestuurdersverkiezing, veel hoger liggen dan die van inwoners. Wethouders moeten, gelet op de uitkomsten van dit onderzoek, oppassen voor het leven in een "mutual admiration society", een eigen bubbel waarin zij zichzelf dus een te positief oordeel aanmeten (...). De blik vanuit inwoners is een relevante en nodige aanvulling op de goede uitoefening van het wethouderschap. Ook is er, blijkens de scores die inwoners geven, meer aandacht nodig voor de 'kleine kwaliteit van leven' van inwoners. Inwoners vragen nadrukkelijk te luisteren naar de zorgen en wensen die zij hebben. Zij hebben behoefte aan een praktische oplossing van wellicht in de ogen van bestuurders "kleine zorgen". Voor individuele inwoners kan dat echter iets heel "groots" zijn.'

We denken dat met deze bijdragen het themadeel 'Op zoek naar succesvol gezag in het lokaal bestuur' voldoende aanknopingspunten biedt voor verder onderzoek naar gezag in het lokaal bestuur, maar ook voor gemeentesecretarissen en wethouders die dag in dag uit hun gezag moeten waarmaken.

\section{Literatuur}

Boonstra, W. (2019). Prijskaartje aan vertrek gemeentesecretaris. Binnenlands Bestuur, 24 januari. https://www.binnenlandsbestuur.nl/ambtenaar-en-carriere/nieuws/ prijskaartje-aan-vertrek-gemeentesecretaris.9606404.lynkx

Brons C., \& Jansen, T. (red.) (2018). Gezag en geloofwaardigheid van lokale politieke bestuurders (themanummer). Bestuurskunde, 27(3).

Karsten, N. (2015). 'Maar ze hebben er wel over nagedacht': Over de rol van gezag bij het voorkomen van vijandigheid jegens politieke ambtsdragers. Bestuurswetenschappen, 69(1), 66-76.

Karsten, N. (2013). Decide and defend: Regaining authority for controversial decisions through rendering account. Rotterdam: Optima Grafische Communicatie.

Karsten, N., \& Jansen, T. (2013). Veranderend lokaal gezag. Beleid \& Maatschappij, 40(4), 378-400.

Meulen, C. van der, Jansen, T., \& Karsten, N. (2019). Het gezag van de gemeentesecretaris: Een ambachtelijke uitdaging. Stichting Beroepseer \& Vereniging voor Gemeentesecretarissen.

Meulen, C. van der, \& Jansen, T. (2018). Het gezag van de wethouder: Een ambachtelijke uitdaging. Stichting Beroepseer \& Wethoudersvereniging.

Meulen, C. van der, Jansen, T., \& Karsten, N. (2018). Hoe wethouders hun eigen gezag waarnemen. Bestuurskunde, 27(3), 43-55. 